\title{
CoOperation of European Manufacturing COMPANIES
}

\author{
PALCIC, I.; POlAJNAR, A.; BUCHMEISTER, B.; \\ LEBER, M. \& VUJICA HERZOG, N.
}

Abstract: This chapter presents the existing state of cooperation issues among European manufacturing firms. We have conducted a survey within several European countries and asked their manufacturing firms with at least 20 employees if they are keen to cooperate with other firms and other institutions in the field of $R \& D$, production, sales, distribution, education and training etc. The authors present results and interpret the cooperation patterns in different countries.

Key words: production, cooperation, survey, $R \& D$
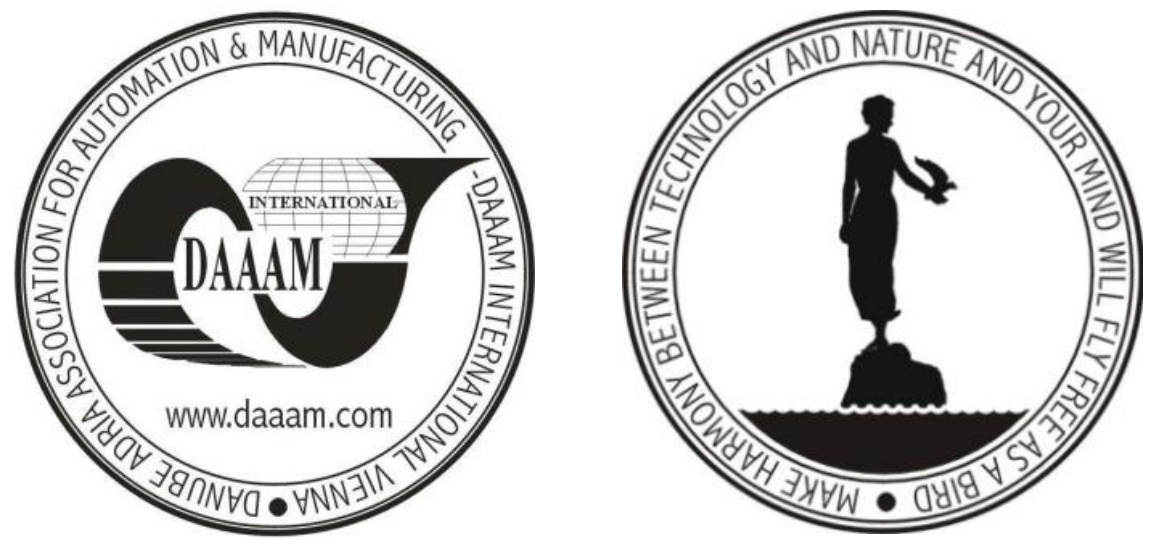

Authors' data: Ass. Prof. Dr. Palcic, I[ztok]; Full. Prof. Dr. Polajnar, A[ndrej]; Assoc. Prof. Dr. Buchmeister, B[orut]; Ass. Prof. Dr. Leber, M[arjan]; Ass. Prof. Dr. Vujica Herzog, N[atasa], University of Maribor, Faculty of Mechanical Engineering, Smetanova ulica 17, 2000, Maribor, Slovenia, iztok.palcic@uni-mb.si, andrej.polajnar@uni-mb.si, borut.buchmeister@uni-mb.si, marjan.leber@uni-mb.si, natasa.vujica@uni-mb.si

This Publication has to be referred as: Palcic, I[ztok]; Polajnar, A[ndrej]; Buchmeister, B[orut]; Leber, M[arjan] \& Vujica Herzog, N[atasa] (2010). Cooperation of European Manufacturing Companies, Chapter 04 in DAAAM International Scientific Book 2010, pp. 027-040, B. Katalinic (Ed.), Published by DAAAM International, ISBN 978-3-901509-74-2, ISSN 1726-9687, Vienna, Austria DOI: $10.2507 /$ daaam.scibook.2010.04 


\section{Introduction}

Modern business environment characterized by high competitiveness and frequent turbulences make firms aware on the benefits and outcomes of possible cooperative agreements. The ever growing amount of new knowledge and birth of new technologies make firms specialize in order to achieve excellence in at least one specific area. OEMs transfer their activities to their suppliers. The knowledge is distributed among industries, but there is a need for interdisciplinary approach in new product and service development. This approach can only be achieved by linking firms with other actors.

We are surrounded with new business forms, such as business networks, technological networks, industrial clusters, platforms, virtual organisations, living laboratories etc. The actors in this business forms have all identified a need to cooperate with other partners. There are also different areas where firms cooperate with other actors. Firms can cooperate in the area of R\&D, manufacturing, purchase, sales, distribution, education, training, ICT issues, marketing etc. This chapter will provide characteristics of cooperative behaviour of manufacturing firms in six European countries: Spain, Germany, Austria, Switzerland, Croatia and Slovenia.

The chapter focuses on two wider points of analysis. First analysis deals with different areas of cooperation within each country. We will present results on how firms cooperate in the following areas:

- R\&D area with universities and other research institutions,

- R\&D area with other firms (customers and suppliers excluded),

- Production (manufacturing) area,

- Purchasing area,

- Service area / sales area / distribution area,

- Education and training area.

Second analysis has a threefold purpose. First we are going to take a look at how firms in all countries cooperate based on the geographical distances between them and other actors. We have divided geographical distances into three areas:

- less than $50 \mathrm{~km}$ - regional cooperation,

- more than $50 \mathrm{~km}$ - national cooperation and

- cooperation with firms outside national borders - international cooperation.

Another interesting research topic was willingness of firms to engage in cooperative agreement with more than one partner. We wanted to find out how bilateral agreements are slowly changing into network cooperative agreements with more than one partner. Besides national differences we were interested in cooperative patterns in all previously mentioned areas within each country.

Social capital, trust, tacit and explicit knowledge spill-overs play a huge role when firms decide to cooperate with other actors. To protect their knowledge and competitive position they engage in cooperative agreements with various levels of formality. Again, we looked at national characteristics regarding formality of cooperation among firms and other actors and we have also explored the dependence between formality of the network and specific cooperation area (Palcic et al., 2008). 


\section{Methodology}

Presented data on cooperation issues is a result of European Manufacturing Survey. The European Manufacturing Survey (EMS) was conducted in 2003/2004 as a pilot survey in nine European countries. The survey covers Austria, Croatia, France, Germany, Great Britain, Italy, Slovenia, Switzerland and Turkey. In total 2249 firms answered questions concerning manufacturing strategies, the application of innovative organisational and technological concepts in production and questions of personnel deployment and qualification. In addition, data on performance indicators such as productivity, flexibility, quality and returns was collected. The responding firms present a cross-section of the main manufacturing industries. Producers of rubber and plastics are represented by 11 percent, producers of metal works by 27 percent, mechanical engineering by 31 percent and electrical engineering by 10 percent. In the year 2006 a new survey was conducted in even more European countries, where Greece, Netherlands and Spain joined the project. We have received around 4000 responses from European manufacturing firms. As already mentioned this chapter provides characteristics of cooperative behaviour of manufacturing firms in six European countries: Spain, Germany, Austria, Switzerland, Croatia and Slovenia. We have also already described the formulation of the cooperation question that is a part of this survey. Figure 1 depicts this question in a survey. Does your factory co-operate with other companies in any of the following areas? (cooperation = voluntary cooperation
between different companies beyond once-only orders)
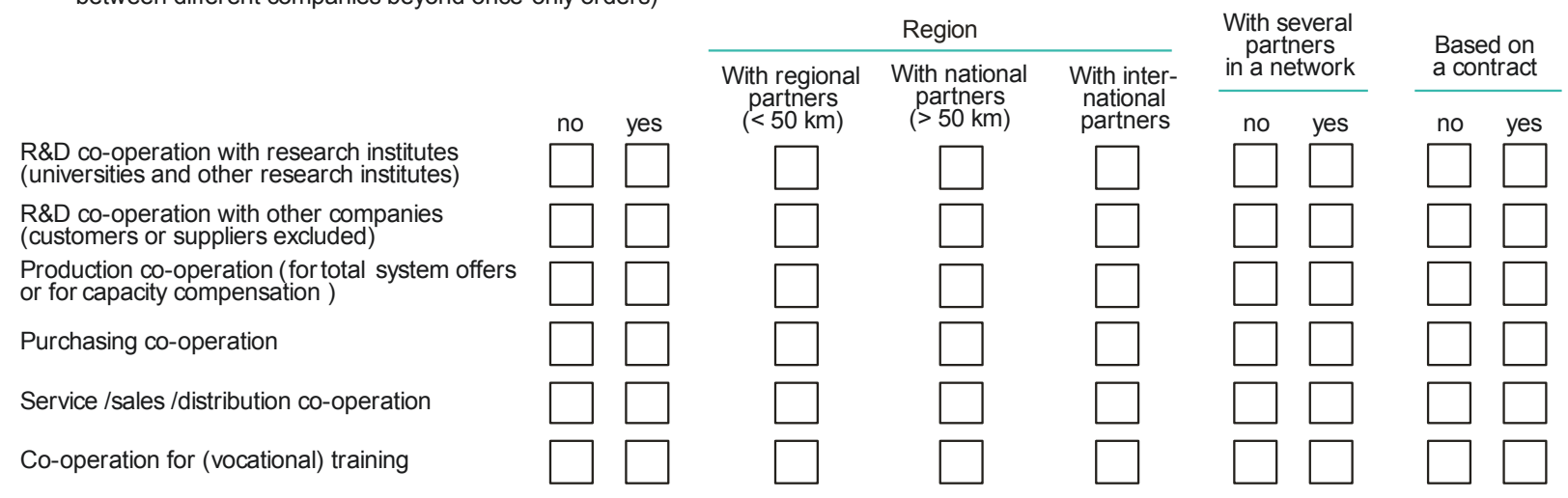

Fig. 1. Question on cooperation issues

There were almost 3000 firms included in the survey with the national structure presented in Table 1.

\begin{tabular}{|l|c|c|}
\hline \multicolumn{1}{|c|}{ Country } & No. of firms & Percentage \\
\hline Germany & $\mathbf{1 6 6 3}$ & 56,09 \\
\hline Swiss & $\mathbf{6 9 0}$ & 23,27 \\
\hline Austria & $\mathbf{2 8 1}$ & 9,48 \\
\hline Spain & $\mathbf{1 5 1}$ & 5,09 \\
\hline Croatia & $\mathbf{1 0 8}$ & 3,64 \\
\hline Slovenia & $\mathbf{7 2}$ & 2,43 \\
\hline \multicolumn{1}{|r|}{ TOTAL } & $\mathbf{2 9 6 5}$ & $\mathbf{1 0 0}$ \\
\hline
\end{tabular}

Tab. 1. Participating firms included in EMS 
It is obvious that the German sub-sample is the most dominant. Therefore the previously described analysis was performed on the level of each country separately to get a better picture of the cooperation issues. We have also made a comparison between all included countries.

\section{Cooperation within specific firm areas}

There are several areas where manufacturing firms engage in cooperative relationship with other actors:

- R\&D area with universities and other research institutions,

- R\&D area with other firms (customers and suppliers excluded),

- Production (manufacturing) area,

- Purchasing area,

- Service area / sales area / distribution area,

- Education and training area.

Many researchers have proved the importance of cooperation in all mentioned areas. A special focus is on $R \& D$ cooperation between firms and $R \& D$ institutions and with other firms, also competitors (e.g. like in industrial clusters). Why are firms cooperating in $R \& D$ area with universities? There are several reasons according to Veugelers and Cassiman (2006):

- Since universities are no direct competitors in the output markets of the collaborating firm, not being able to appropriate exclusively the benefits from the new know-how generated is not an issue for firm-university cooperation, as it is in cooperation among firms competing in output markets, unless the know-how would leak out to competitors indirectly through common partners.

- Science institutions offer new technical knowledge which is mainly needed in innovation activities oriented towards developing new technologies and for products very new to the market. These innovation activities take place in the early stages of the innovation process characterized by high technological uncertainty and still low demand for the outcomes of innovation activities (Jensen et al., 2003).

- Given the specific characteristics of scientific knowledge, R\&D cooperation between universities and industry is characterized by high uncertainty, high information asymmetries between partners, high transaction costs for knowledge exchange requiring the presence of absorptive capacity, high spill-overs to other market actors (i.e. a low level of appropriation of benefits out of the knowledge acquired), and, restrictions for financing knowledge production and exchange activities due to risk-averse and short-term oriented financial markets. In addition, enforcing partner compliance in cooperative contracts will be more difficult when the technology is characterized by a large amount of uncertainty. Nevertheless, the more generic nature of research projects with universities and research institutes involves less intellectual property right issues.

The results show that almost half of firms in each country cooperate with R\&D institutions. That was quite a surprising finding as other studies show lower numbers. 
A more in-depth survey is needed to find out in what kind of cooperative agreement in $R \& D$ area firms engage in with $R \& D$ institutions.

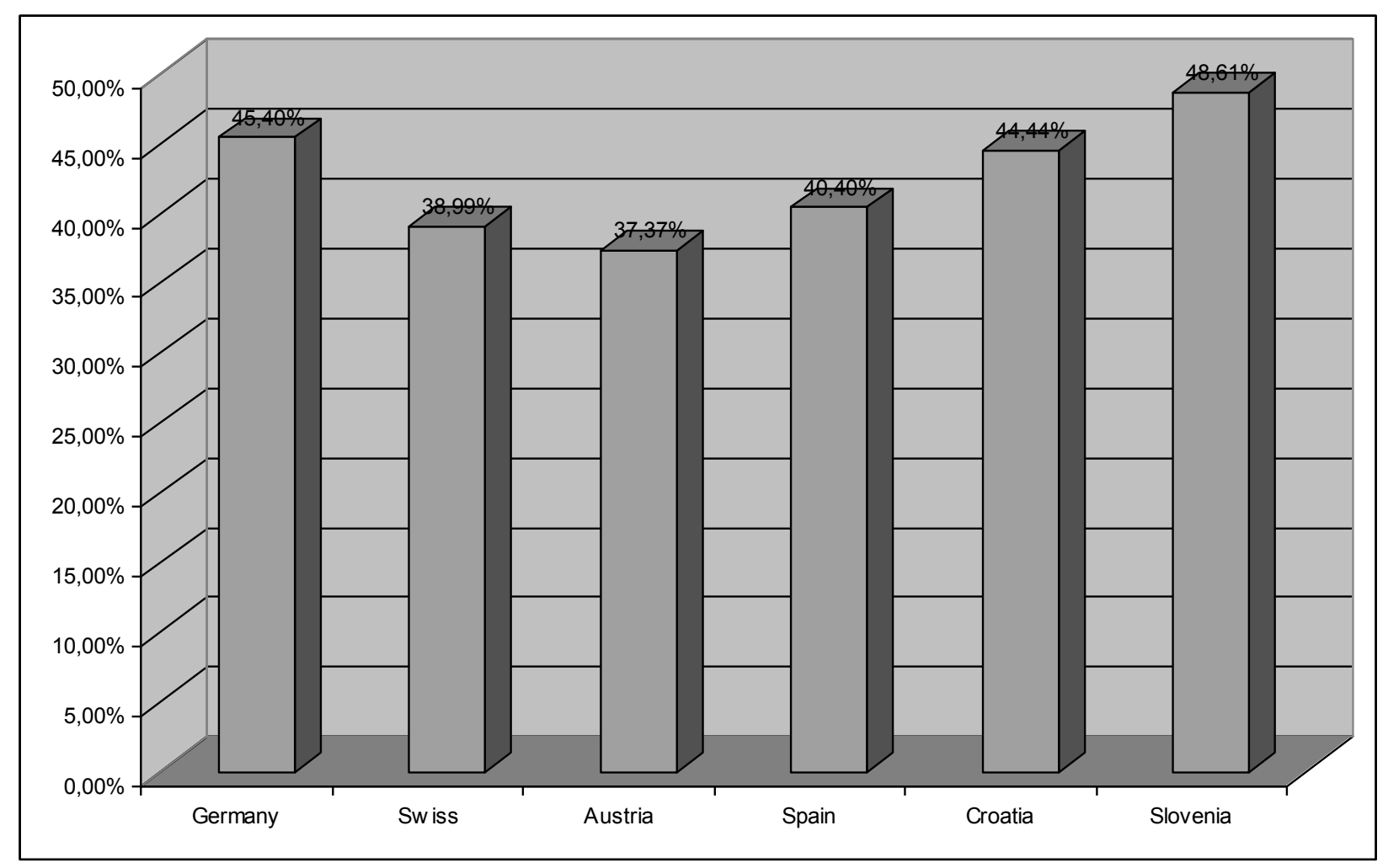

Fig. 2. R\&D cooperation with $R \& D$ institutions

R\&D partnerships among firms are part of a relatively large and diverse group of inter-firm relationships that one finds in between standard market transactions of unrelated firms and integration by means of mergers and acquisitions (Hagedoorn, 2002). There are different types of R\&D partnerships: e.g. contractual partnerships, such as joint $R \& D$ pacts and joint development agreements, and equity-based joint ventures. Joint ventures are certainly one of the older modes of inter-firm partnering. Joint ventures, including those with a specific R\&D program, have become wellknown during the past decades (Berg et al., 1982; Hagedoorn, 1996; Hladik, 1985). Joint ventures are organizational units created and controlled by two or more parentfirms and as such they increase the organizational interdependence of the parent firms. Recent studies have established that non-equity, contractual forms of R\&D partnerships, such as joint R\&D pacts and joint development agreements, have become very important modes of inter-firm collaboration as their numbers and share in the total of partnerships has far exceeded that of joint ventures (Hagedoorn, 1996; Narula \& Hagedoorn, 1999; Osborn \& Baughn, 1990). These contractual agreements cover technology and R\&D sharing between two or more firms in combination with joint research or joint development projects. Such undertakings imply the sharing of resources, usually through project-based groups of engineers and scientists from each parent-firm. The costs for capital investment, such as laboratories, office space, equipment, etc. are shared between the partners. 
Palcic, I.; Polajnar, A.; Buchmeister, B.; Leber, M. \& Vujica Herzog, N.: Cooperation ...

It is no surprise that the percentage of firms cooperating in $R \& D$ area with other firms is lower than in case with R\&D institutions. Approximately one third of firms admitted this cooperation. The only exception is Slovenia with a bit higher rate. This can be a consequence of the fact that majority of surveyed firms were a part of some kind formal network organisations that were promoted in Slovenia at the beginning of this century (e.g. industrial cluster, technological platforms). We could conclude that this formal network business forms lead to a higher cooperative behaviour in R\&D projects (Figure 3).

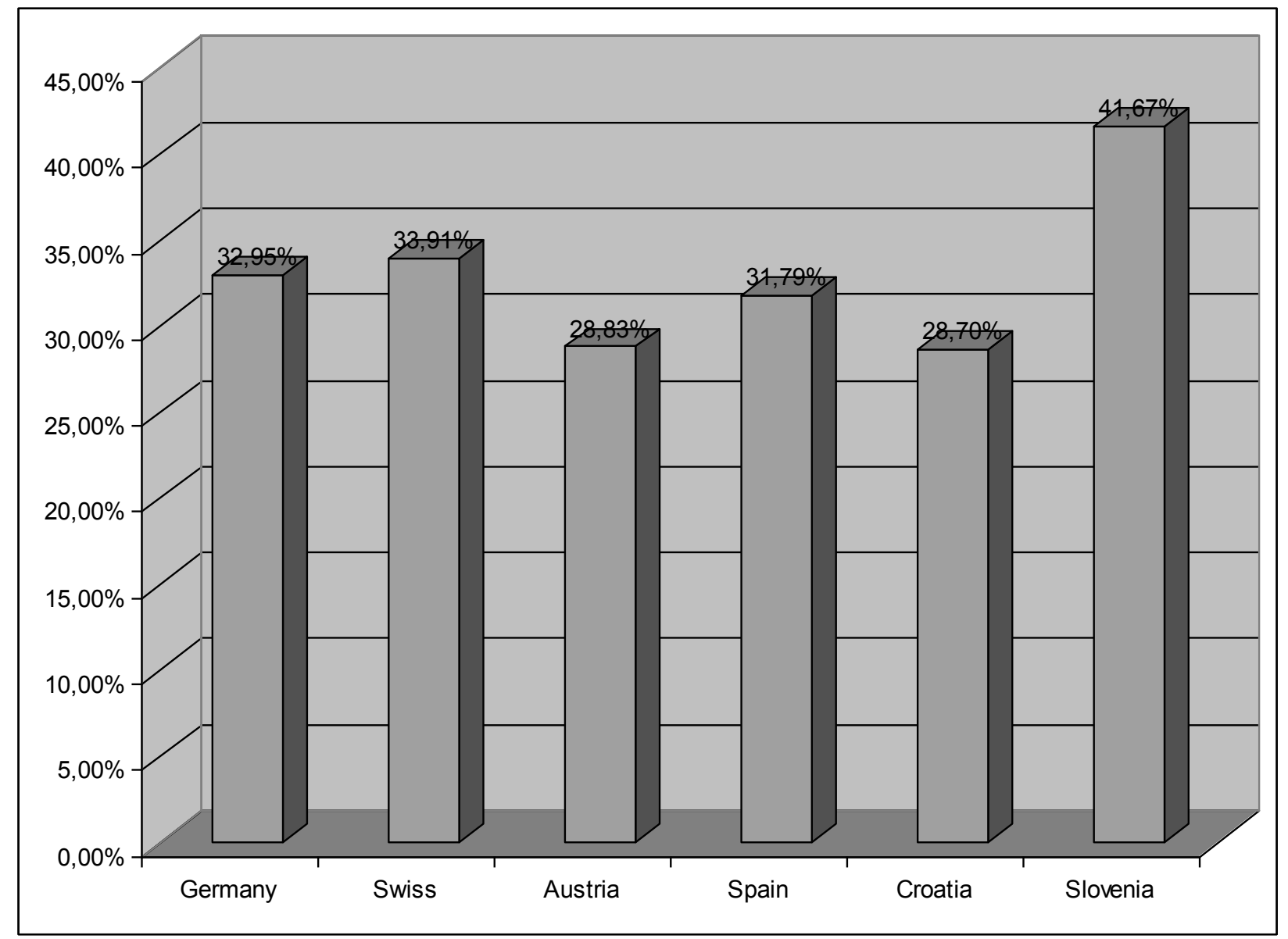

Fig. 3. R\&D cooperation with firms

Production cooperation covers many different possibilities and reasons for it:

- production of new product prototypes (result of R\&D cooperation with other firms),

- exchanging free machine capacities,

- outsourcing a part of production to partners (lack of knowledge, equipment, overloaded capacities),

- joint production and assembly with suppliers or even customers (OEMs),

- etc.

There are quite substantial differences in production cooperation among countries (Figure 4). In Western countries approximately one third of firms cooperate with other firms in production activities, while the percentage in Croatia and Slovenia 
is quite higher. This can be due to the fact that a lot of firms in these two countries are suppliers and they cooperate with domestic and mostly foreign OEMs.

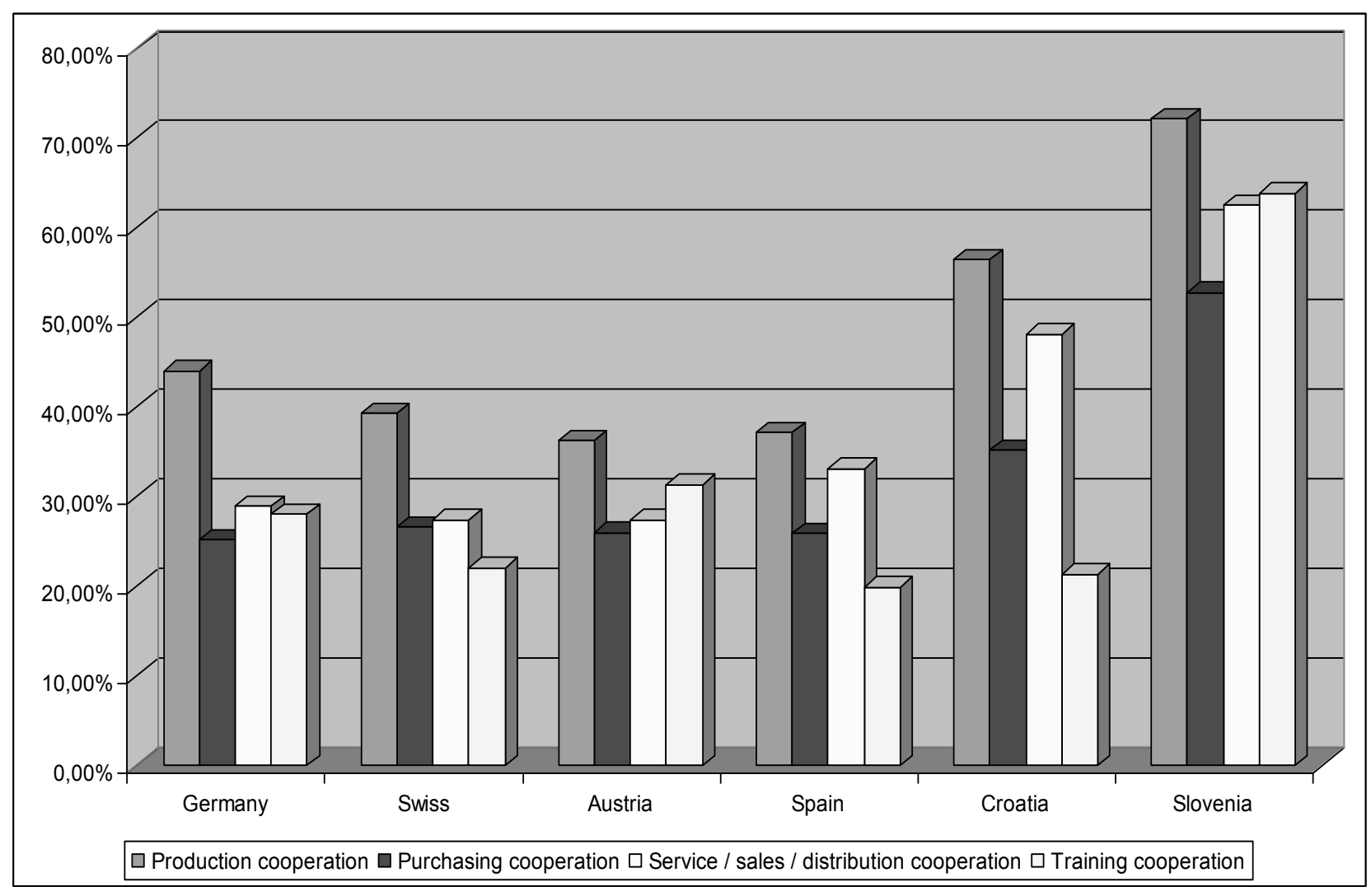

Fig. 4. Production, purchasing, service-sales-distribution, education-training cooperation

Similar story as with production cooperation can be seen in three other cooperation areas: purchasing, service-sales-distribution and education-training cooperation. The overall impression is that firms in Western countries are less keen to cooperate than in Croatia and Slovenia. Especially surprising is the low level of joint purchasing cooperation. It is widely acknowledged that joint purchase of input materials, raw materials (e.g. steel) together with other firms (even competitors) can be much more cost effective than single purchase, where you can hardly bargain good prices and delivery dates with strong suppliers. In the sales area firms are also not using enough joint mechanism to penetrate and conquer new markets with their products and services. Especially, small and medium sized firms should be aware that isolated market approach could be much harder than sales relationships with other (bigger, more established) firms. One could also conclude that firms do not look for a help of agents in sales, service and distribution area, meaning that they want to control the whole value chain by themselves. We can argue that this is too demanding for many, especially smaller firms that have a lack of knowledge, finance and other resources. Training and education cooperation is also quite low. A lot of bigger firms have internal training and education processes, tailored to their needs. Joint training can also be seen as knowledge spill-over process that can threaten firm's competitive advantage. 
Palcic, I.; Polajnar, A.; Buchmeister, B.; Leber, M. \& Vujica Herzog, N.: Cooperation ...

A closer look at all cooperation areas brings us to the following. Slovenia and Croatia engage into more cooperative agreements as the other four countries. Both countries went through a radical change of economic system in the last 15 years. The firms in these two countries are aware of their disadvantages that can be only removed by intensive cooperation with domestic and foreign actors. Germany, Switzerland, Austria and Spain show quite similar cooperation patterns. The latter two are countries, where firms are the most reluctant to cooperate. To explain these findings more in detail we have to take a look another three cooperation issues: geographical issues, number of partners in cooperative agreements and the formality of cooperation. We have to point out that in all following analysis we have included only firms that have stated that they cooperate in specific areas.

\begin{tabular}{|l|c|c|c|c|c|c|}
\hline & Germany & Swiss & Austria & Spain & Croatia & Slovenia \\
\hline $\begin{array}{l}\text { R\&D cooperation } \\
\text { with R\&D } \\
\text { institutions }\end{array}$ & $45,40 \%$ & $38,99 \%$ & $37,37 \%$ & $40,40 \%$ & $44,44 \%$ & $48,61 \%$ \\
\hline $\begin{array}{l}\text { R\&D cooperation } \\
\text { with firms }\end{array}$ & $32,95 \%$ & $33,91 \%$ & $28,83 \%$ & $31,79 \%$ & $28,70 \%$ & $41,67 \%$ \\
\hline $\begin{array}{l}\text { Production } \\
\text { cooperation }\end{array}$ & $44,02 \%$ & $39,28 \%$ & $36,30 \%$ & $37,09 \%$ & $56,48 \%$ & $72,22 \%$ \\
\hline $\begin{array}{l}\text { Purchasing } \\
\text { cooperation }\end{array}$ & $25,14 \%$ & $26,52 \%$ & $25,98 \%$ & $25,83 \%$ & $35,19 \%$ & $52,78 \%$ \\
\hline $\begin{array}{l}\text { Service / sales / } \\
\text { distribution } \\
\text { cooperation }\end{array}$ & $28,92 \%$ & $27,39 \%$ & $27,40 \%$ & $33,11 \%$ & $48,15 \%$ & $62,50 \%$ \\
\hline Training cooperation & $27,96 \%$ & $22,03 \%$ & $31,32 \%$ & $19,87 \%$ & $21,30 \%$ & $63,89 \%$ \\
\hline
\end{tabular}

Tab. 2. Percentage of firms that cooperate in specific areas

\section{Cooperation and geographical issues}

It is a well known fact that geographical proximity still plays a vital role in cooperative agreements. Although we are living in the age of globalisation and in an economy with rapid transportation and communication global markets are easily accessible, cooperative agreements' success still very much depends on the physical proximity of partners. It has been widely recognized that changes in technology and competition have diminished many of traditional roles of location. Resources, capital and other inputs can be efficiently sourced in global markets. Firms can access immobile inputs via corporate networks. They need no longer locate near large markets. Information and relationship than can be accessed and maintained via fax or e-mail are available to anyone. But on the other hand, the enduring competitive advantages in a global economy are often heavily local, arising from concentrations of highly specialized skills and knowledge, institutions, rivals, related businesses and sophisticated customers in a particular nation or region. Proximity in geographic, cultural and institutional terms allows special access, special relationships, better information, powerful incentives and other advantages in productivity and productivity growth that are difficulty to tap from a distance. Standard inputs, information and technologies are readily available via globalization, then, while more 
advanced dimensions of competition remain geographically bounded. Having that in mind, let us take a look how geographical distances affect cooperation within all six areas.

We have divided geographical distances into three areas:

- less than $50 \mathrm{~km}$ - regional cooperation,

- more than $50 \mathrm{~km}$ - national cooperation and

- cooperation with firms outside national borders - international cooperation.

Regionally firms like to cooperate in $R \& D$ area with other $R \& D$ institutions and especially in joint education and training. We can explain that by assuming that firms are more familiar with local (regional) universities and other R\&D institutions, which can provide new knowledge and help in development of new products and services. Trust and social capital as already mentioned are very important elements of $R \& D$ cooperation. Spain is particularly locally and regionally oriented when it comes to cooperation in R\&D and education area (Figure 5).

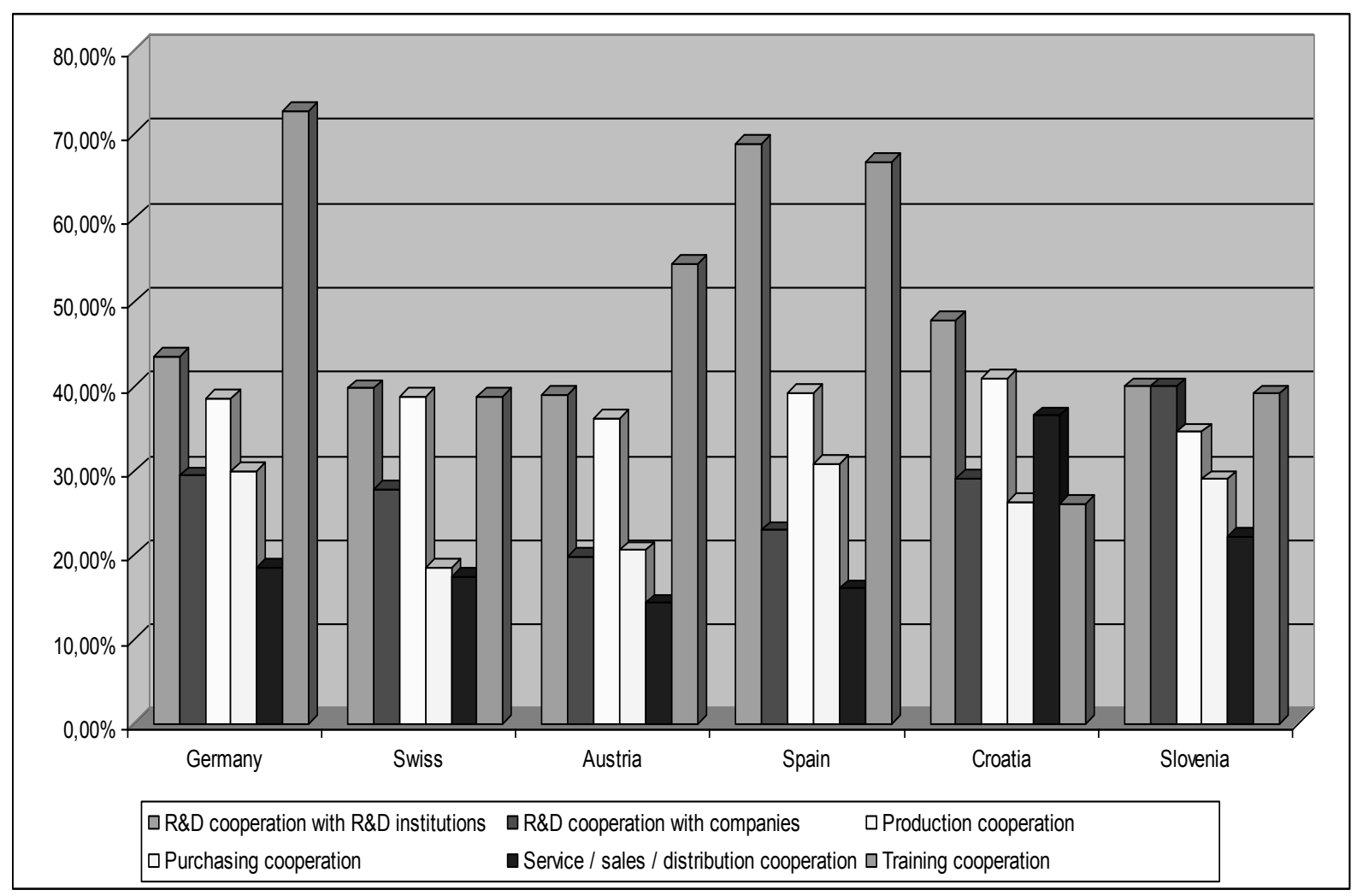

Fig. 5. Regional cooperation of firms in specific areas

Looking at the national level we can see that R\&D cooperation with domestic $R \& D$ institutions and firms is still very present. At the same time other forms of cooperation, especially production, purchasing and sales-service-distribution cooperation are more present on national level than on just regional. These results are no surprise as local markets are not big enough for majority of firms. There are big similarities among all countries at national level cooperation, where Germany is perhaps most keen on national cooperation in all areas except education (Figure 6). 
Palcic, I.; Polajnar, A.; Buchmeister, B.; Leber, M. \& Vujica Herzog, N.: Cooperation ...

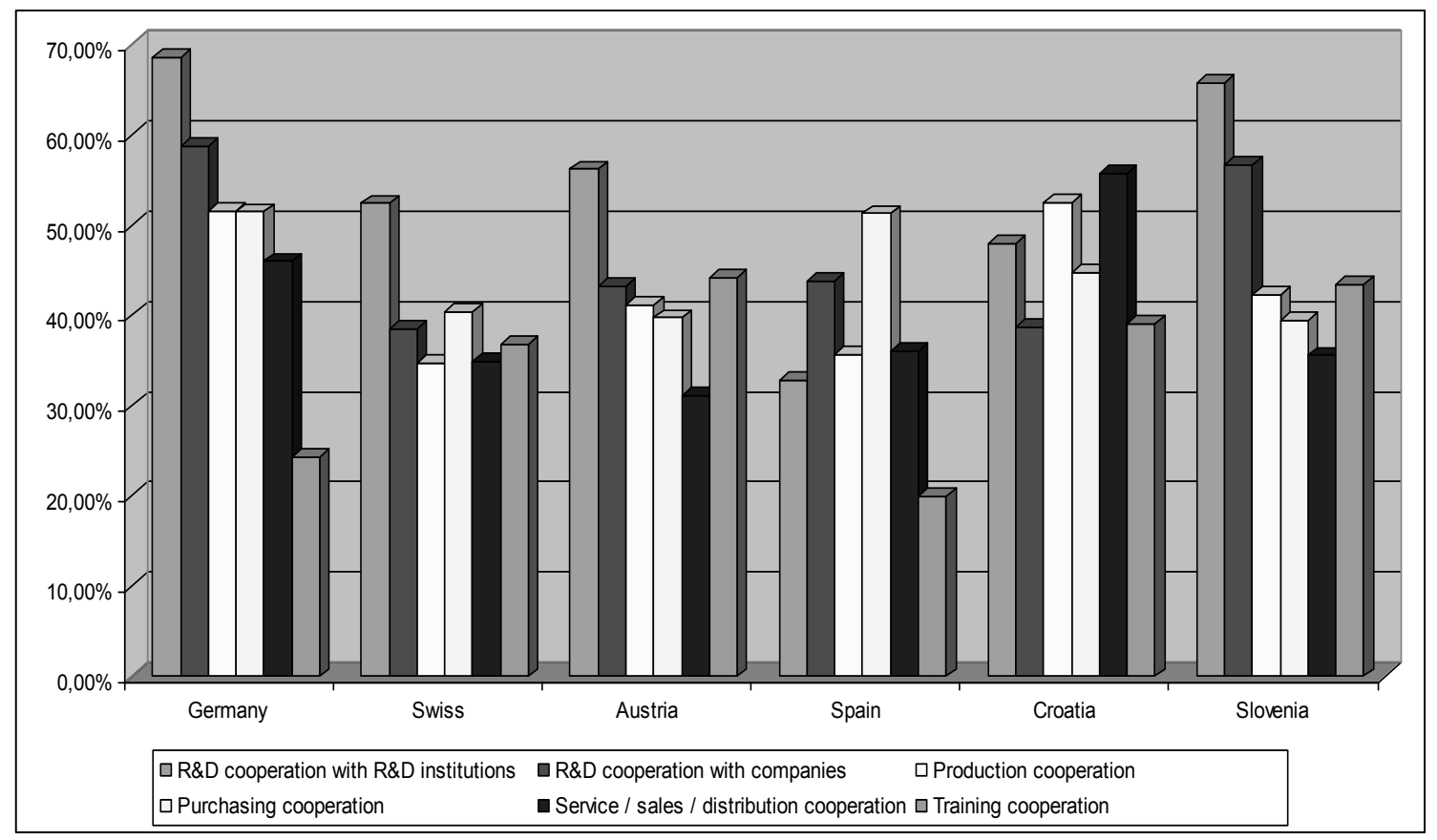

Fig. 6. National cooperation of firms in specific areas

The picture completely changes in cooperation with international actors outside national borders. The percentage of firms that cooperate in $R \& D$ area with other $\mathrm{R} \& \mathrm{D}$ institutions is much lower, cooperation in education and training is also lower. But on the other hand cooperation in purchasing, sales-service-distribution is quite higher. A lot of firms are looking for partners on international markets and they are obviously export oriented. This means that they have to look for partners abroad in order to penetrate into foreign markets. A bit surprising is high level of R\&D cooperation with other firms. We assume that a lot of firms are cooperating in international network organisations and taking part in cross-border development projects (Figure 7).

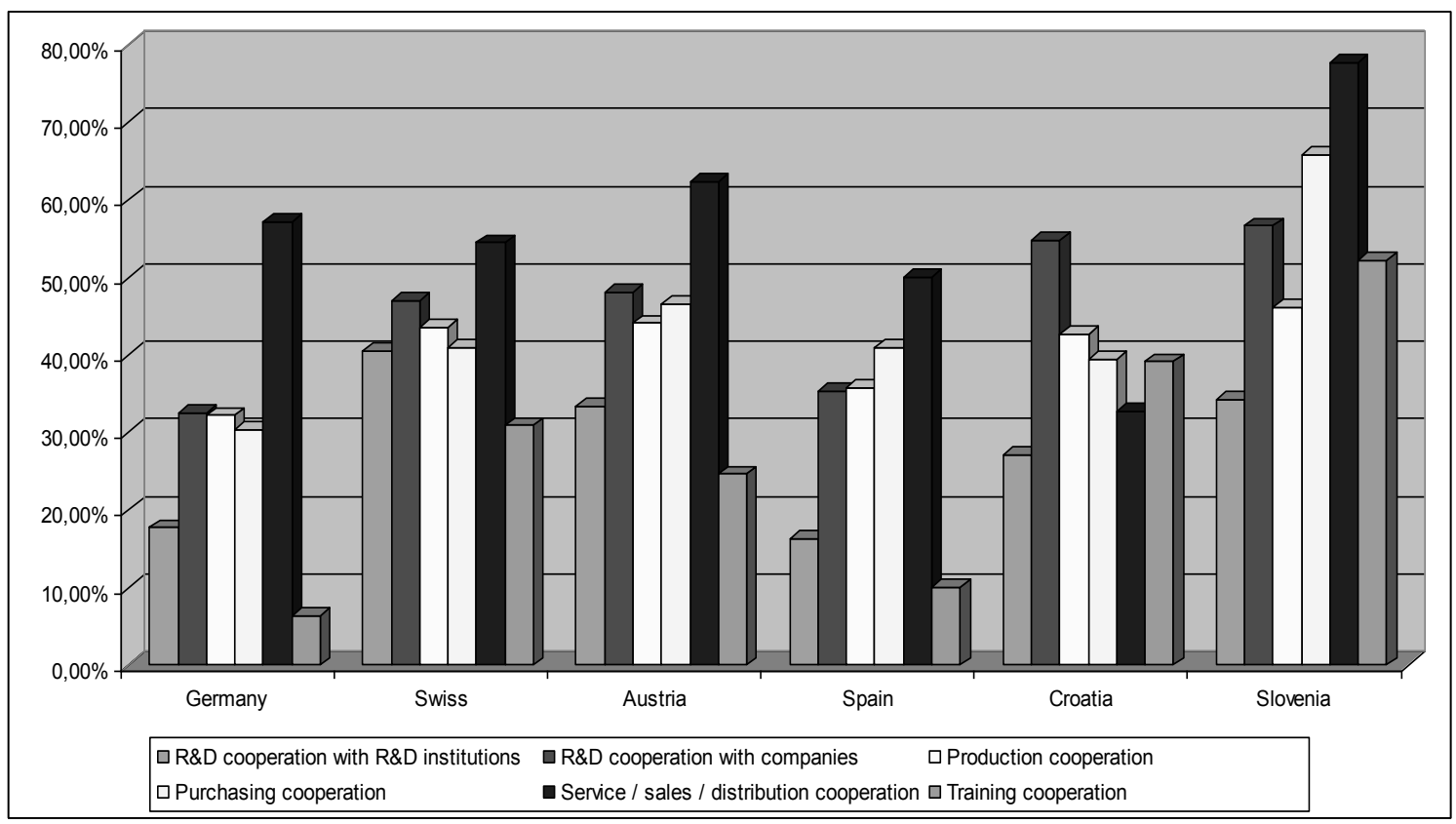

Fig. 7. International cooperation of firms in specific areas 
Table 3 summarises our findings for cooperation and geographical proximity issues. For each cooperation area and each country we have determined the prevailing relationship with the following grades:

$1-$ majority of firms cooperates $<50 \mathrm{~km}=$ REGIONAL

$2-$ majority of firms cooperates $>50 \mathrm{~km}=$ NATIONAL

$3-$ majority of firms cooperates across borders $=$ INTERNATIONAL

\begin{tabular}{|c|c|c|c|c|c|c|c|}
\hline $\begin{array}{ll}\text { Cooper. area } & \text { Country } \\
\end{array}$ & GER & SWI & AUS & SPA & CRO & SLO & Characteristics \\
\hline $\begin{array}{l}\text { R\&D with R\&D } \\
\text { institutions }\end{array}$ & 2 & 2 & 2 & 1 & 1,2 & 2 & $\mathbf{R} / \mathbf{N}$ \\
\hline R\&D with firms & 2 & 3 & 3 & 2 & 3 & 2,3 & $\mathbf{N} / \mathbf{I}$ \\
\hline Production & 2 & 3 & 3 & 1 & 2 & 3 & $\mathbf{N} / \mathbf{I}$ \\
\hline Purchase & 2 & 3 & 3 & 2 & 2 & 3 & $\mathbf{N} / \mathbf{I}$ \\
\hline Sales / services & 3 & 3 & 3 & 3 & 2 & 3 & I \\
\hline Education / training & 1 & 1 & 1 & 1 & 2,3 & 3 & $\mathbf{R} / \mathbf{I}$ \\
\hline Characteristics & $\mathbf{N}$ & $\mathbf{I}$ & $\mathbf{I}$ & $\mathbf{R} / \mathbf{N}$ & $\mathbf{N}$ & $\mathbf{I}$ & \\
\hline
\end{tabular}

Tab. 3. Cooperation patterns depending on geographical proximity of partners

The results suggest the following:

- Majority of cooperation activities is becoming more and more independent from geographical distances. The only exception is still cooperation within R\&D and education area with R\&D institutions and sometimes other firms. This proves the theory about knowledge still being local commodity and a source of competitive advantage, but on the other hand it is a cornerstone for national and international activities and cooperation in production, sales, purchasing, distribution etc.

- Smaller countries as Switzerland, Austria and Slovenia are looking more and more for international partners. Domestic markets and simply not big enough. Germany is the strongest European economy with a market that allows national orientation in majority of activities, but at the same time the German firms are also very export oriented and they look especially for sales cooperation in other countries. Spain is on the other hand very regionally oriented, meaning that in majority of activities firms look for local partners. The only exception is sales activities.

\section{Cooperation, networking and formality}

In the end we have asked manufacturing firms about two more cooperation characteristics, namely do they engage into bilateral or multilateral cooperative agreements and what is the level of formality of their cooperation. Our assumption was that firms more and more cooperate within all activities with more than just one partner. The results are slowly confirming our assumption. In Germany, Switzerland and Austria approximately $40 \%$ of firms cooperates with several partners in practically all areas. Spain is again a bit different, as only one out of five firms on average cooperates with more than one partner. Although firms in Slovenia and Croatia like to cooperate in all areas, only one third of firms do that with more than one partner (Figure 8). 
Palcic, I.; Polajnar, A.; Buchmeister, B.; Leber, M. \& Vujica Herzog, N.: Cooperation ...

The formality of cooperative agreements varies from strictly contractual agreements to informal oral agreements. We were interested into strictly formal contractual agreements before actual cooperation begins. It was interesting to notice that there were not big differences among countries. This is quite surprising if we consider differences in business culture and mentality of nations. Bigger differences were in specific areas. As expected the majority of formal agreements occur in R\&D cooperation. This is no surprise as knowledge and information exchange is a source of competitive advantage and, of course, subject of intellectual property rights. A high level of formal cooperation was also evident in joint sales activities. Since majority of firms acknowledged that they cooperate in sales activities with foreign partners, formal agreements are necessary (Figure 9).

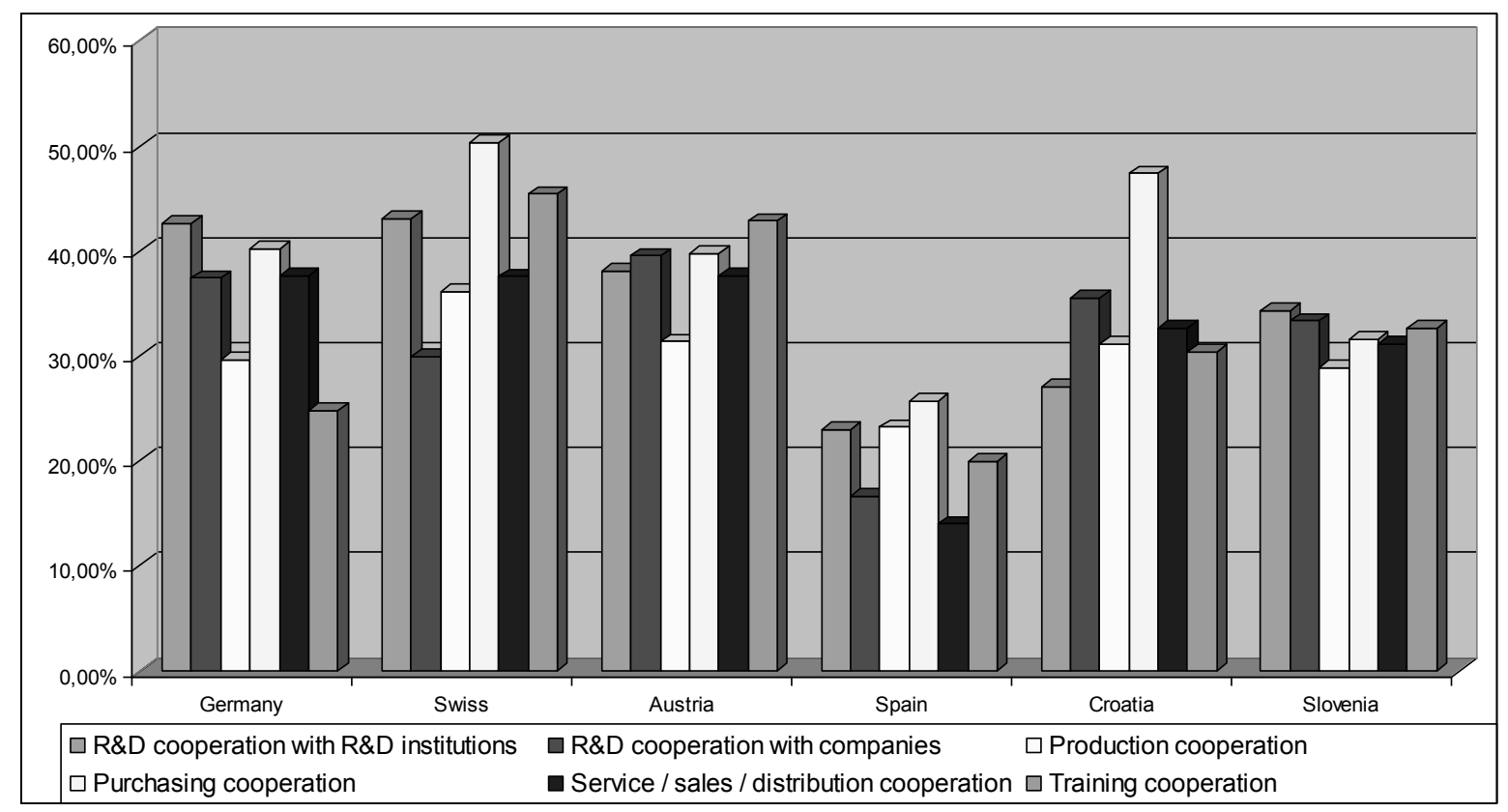

Fig. 8. Firms' cooperation with more than 1 partner in specific areas

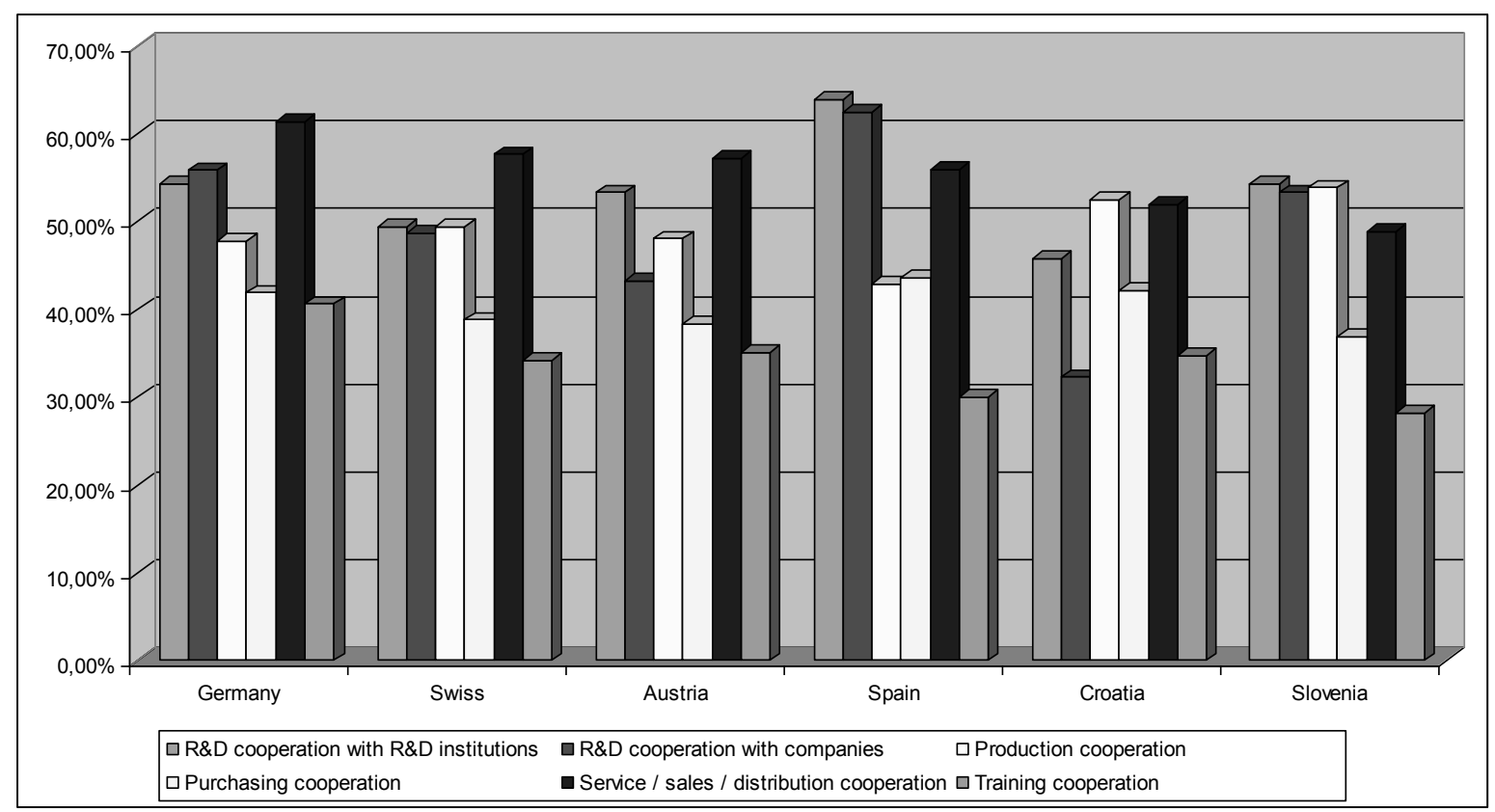

Fig. 9. Formality of firms' cooperation in specific areas 


\section{General findings}

In order to summarise our findings on cooperation of manufacturing firms in six European countries, we have prepared a simplified matrix that consists of three dimensions:

- Share of firms in each country that cooperate in specific areas (for all six cooperation areas),

- Share of firms in each country that cooperate with more than one partner (for all six cooperation areas),

- Share of firms in each country that cooperate in a formal way (for all six cooperation areas).

We have ranked the countries based on three criteria. This is extremely simplified ranking, where one should be aware that the difference between rank 1 and 6 can be quite small. It is just a general presentation of cooperation patterns in six selected countries.

\begin{tabular}{|l|c|c|c|}
\hline Criteria & $\begin{array}{c}1-\text { the highest share of } \\
\text { firms that cooperate in a } \\
\text { specific area } \\
6-\text { the lowest share of } \\
\text { firms that cooperate in a } \\
\text { specific area }\end{array}$ & $\begin{array}{c}1-\text { the highest number of } \\
\text { partners in a specific } \\
\text { cooperation area } \\
6-\text { the lowest number of } \\
\text { partners in a specific } \\
\text { cooperation area }\end{array}$ & $\begin{array}{c}1-\text { the highest share of } \\
\text { firms that cooperate } \\
\text { formally in a specific area } \\
6-\text { the lowest share of } \\
\text { firms that cooperate } \\
\text { formally in a specific area }\end{array}$ \\
\hline Germany & 3 & 3 & 1 \\
\hline Swiss & 4 & 1 & 3 \\
\hline Austria & 6 & 2 & 2 \\
\hline Spain & 5 & 6 & 5 \\
\hline Croatia & 2 & 4 & 6 \\
\hline Slovenia & 1 & 5 & 3 \\
\hline
\end{tabular}

Tab. 4. Analysis of cooperation behaviour of manufacturing firms in six European countries

General finding for each country can be interpreted as follows:

- German manufacturing firms like to cooperate with many partners, but in a very formal way. They like to cooperate with other actors within national borders, while at the same time they show tendency for international cooperation (especially in sales).

- Switzerland and Austria are extremely similar. Their manufacturing firms show less cooperation activities than firms in other countries. But when they engage in cooperation they like to work with several partners, where cooperative agreements can be formal or informal. Both countries are very internationally oriented.

- Croatia and Slovenia are also quite similar. They have the highest share of firms that cooperate with other actors. Their firms prefer bilateral agreements that are mostly informal. Slovenia is very internationally oriented, while Croatia is still looking to become (joining EU will certainly help their firms).

- Results of the survey for Spanish manufacturing firms were probably the most interesting results of all countries. On average approximately one third of Spanish 
manufacturing firms cooperates in all six areas. Exception is education and training where only one of five firms looks for partners. Looking at the total picture Spain was among the countries where their firms do not cooperate extremely often (only Austria had a slightly lower percentage). But when Spanish manufacturing firms engage in cooperation they prefer bilateral cooperative agreements and are reluctant to cooperate with more than one partner. And what is even more interesting, even within this bilateral agreements their cooperation is mostly very formal (especially in R\&D area and sales). This is not the end of interesting findings. Spain was also the only country where regional cooperation in some cooperation areas prevails above national and international cooperation ( $R \& D$, production and education cooperation).

A more in-depth analysis of the survey will be made in the future, where size of firms, level of R\&D activities and other characteristics will be considered. Nevertheless, these results already show a very good picture of cooperation behaviour in selected European manufacturing firms. This analysis can help each firm to find out what are the basic characteristics of domestic and foreign firms and other actors when it comes to cooperation. The answer to the questions in which countries firms like to cooperate, with how many partners and what is the level of cooperation formality can help firms when they are looking for new partners.

\section{References}

Berg, S. V.; Duncan, J. \& Friedman, P. (1982). Joint Venture Strategies and Corporate Innovation, Oelgeschlager, Cambridge, MA

Hagedoorn, J. (1996). Trends and patterns in strategic technology partnering since the early seventies. Review of Industrial Organization, Vol. 11, 601-616, 15737160

Hagedoorn, J. (2002). Inter-firm R\&D partnerships: an overview of major trends and patterns since 1960. Research Policy, Vol. 31, 477-492, 0048-7333

Hladik, K. J. (1985). International Joint Ventures, Lexington Books, Lexington, MA

Jensen, R.; Thursby, J. \& Thursby, M. (2003). Disclosure and licensing of university inventions: the best we can do with the $\mathrm{s} * * \mathrm{t}$ we get to work with. International Journal of Industrial Organization, Vol. 21, No. 9, 1271-1300, 0167-7187

Narula, R. \& Hagedoorn, J. (1999). Innovating through strategic alliances: moving towards international partnerships and contractual agreements. Technovation, Vol. 19, 283-294, 0166-4972

Osborn, R. N. \& Baughn, C. C. (1990). Forms of interorganizational governance for multinational alliances, Academy of Management Journal, Vol. 33, 503-519, 0001-4273

Palcic, I.; de Castro Vila \& Bikfalvi, A. (2008). Cooperattion of European manufacturing companies, In: European Manufacturing Survey, de Castro Vila; Bikflavi, A. \& Llach Pages, J. (Ed.), La Universitat de Girona, Girona, Spain

Veugelers, R., Cassiman, B. (2005). R\&D cooperation between firms and universities. Some empirical evidence from Belgian manufacturing. International Journal of Industrial Organization, Vol. 23, 355-379, 0167-7187 